\title{
Synergistic Balance of Strength and Corrosion Resistance in Al-Mg-Er Alloys
}

\author{
Haifei Zhou ${ }^{1} \cdot$ Zhouhai Qian $^{1} \cdot$ Mengcheng Zhou ${ }^{2} \cdot$ Xuebing Liu $^{2} \cdot$ Yong $\mathrm{Li}^{2} \cdot$ Xinfang Zhang $^{2}$
}

Received: 11 October 2019 / Revised: 15 November 2019 / Published online: 5 February 2020

(C) The Chinese Society for Metals (CSM) and Springer-Verlag GmbH Germany, part of Springer Nature 2020

\begin{abstract}
High-strength, corrosion-resistant, and lightweight $\mathrm{Al}-\mathrm{Mg}$ alloys perform an important function in harsh coastal service environments. Corrosion resistance is generally inversely correlated with strength; hence, it is difficult to simultaneously optimize both. In this study, a low-magnesium Er-containing Al-based alloy that is stronger and more corrosion resistant than Al-based alloys have been reported. The alloy contains $\mathrm{Er}$, and the precipitation of $\mathrm{Al}_{3} \mathrm{Er}$ within a face-centered cubic matrix is obtained by a series of smelting-casting, heat treatment, and rolling processes. It is presumed that the strengthening phase of $\mathrm{Al}_{3}$ Er pinning dislocations improves alloy strength. It also increases the recrystallization temperature of cold-rolled matrix and induces the distribution of small-angle grain boundaries, thus allowing the alloy to achieve excellent environmental corrosion resistance. As a result, strength and corrosion resistance are simultaneously improved.
\end{abstract}

Keywords $\mathrm{Al}-\mathrm{Mg}$ alloy $\cdot \mathrm{Al}_{3} \mathrm{Er} \cdot$ Strength $\cdot$ Corrosion resistance $\cdot \mathrm{Er}$

\section{Introduction}

The 5xxx series of aluminum alloys, an aluminum-based alloy with magnesium as the main alloying element, is generally used in transport and marine applications. The use of these alloys as high-quality coastal structural materials is influenced by two critical factors that are both complex functions of magnesium content-strength and corrosion resistance. Generally, corrosion resistance and strength are mutually exclusive because of magnesium content [1]. It is common knowledge that magnesium is the major solid solution element in the $5 \times x x$ series of aluminum alloys, and by increasing the $\mathrm{Mg}$ content, the mechanical properties of alloys can be distinctly improved [2]. The corrosion resistance of $\mathrm{Al}-\mathrm{Mg}$ alloys, however, decreases with the increase in magnesium content. This is because the

Available online at https://link.springer.com/journal/40195

Xinfang Zhang

xfzhang@ustb.edu.cn

1 Zhejing Electric Power Corporation Research Institute, Hangzhou 310014, China

2 State Key Laboratory of Advanced Metallurgy, School of Metallurgical and Ecological Engineering, University of Science and Technology Beijing, Beijing 100083, China corrosion potential of the formed $\beta$ phase $\left(\mathrm{Mg}_{2} \mathrm{Al}_{3}\right)$ is an anode related to the aluminum matrix that can form a channel of intergranular corrosion [3]. This explains why the use of 5xxx aluminum alloys causes many corrosion resistance problems under special working conditions, especially in the long-term operation of coastal substation workpieces [4]. In view of this, low-magnesium 5052 aluminum alloy is typically utilized in coastal substations. When it is used under actual service conditions over an extended period of time, however, the problem of poor corrosion resistance still persists. Simply put, it is not sufficient to simply reduce the $\mathrm{Mg}$ content to improve the corrosion resistance of $5 \mathrm{xxx}$ aluminum alloy because such a reduction also degrades the alloy's mechanical performance.

At present, numerous studies on improving corrosion resistance and mechanical properties in high-Mg 5xxx aluminum alloys by adding $\mathrm{Er}$ (a rare earth element) have been performed [5-12]. To optimize the balance between strength and corrosion resistance, a number of researchers have attempted to increase the initial recrystallization temperature by Er addition to form an $\mathrm{Al}_{3} \mathrm{Er}$ phase with an $\mathrm{L1}_{2}$ structure [5, 13-19]. The addition of erbium to Al-Mg alloys has been reported to have improved the corrosion resistance performance in chloride-containing solutions [6]. The thermodynamic calculation of $\mathrm{Al}-5 \mathrm{Mg}$ shows that in strengthening the precipitate phase, $\mathrm{Al}-\mathrm{Er}$ inhibits the formation of $\mathrm{Mg}-\mathrm{Er}$ intermetallic 
compounds and correspondingly improves the corrosion resistance of alloys [20]. The addition of Er can significantly decrease corrosion pitting and improve the corrosion resistance of 5083 aluminum alloys [21]. Erbium is also reported to be effective in increasing the recrystallization temperature of $\mathrm{Al}-\mathrm{Mg}$ alloys as well as grain refinement, which is mainly attributed to the presence of $\mathrm{Al}_{3} \mathrm{Er}$ particles [5]. During the annealing process, the precipitate is pinned at the grain boundary and hinders the boundary's migration; thereafter, the Al-Mg alloy's recrystallization temperature increases [19].

Although the addition of Er to high-magnesium aluminum alloys has been widely studied, it is considerably important to determine how to curtail the corrosion of low-magnesium aluminum alloys, which are employed for long-term service in coastal conditions. With the idea of improving the properties of high-magnesium aluminum alloys by adding Er, this study investigates whether Er also has a positive effect on low-magnesium aluminum alloys. To date, the reports on the influence of Er on the electrochemical properties or general corrosion and physical properties of low-magnesium aluminum alloys are limited.

In this work, the effect of Er addition on the corrosion resistance and tensile strength of low-magnesium aluminum alloys is investigated. The addition of Er is employed to optimize the corrosion resistance and strength of 5052 aluminum alloy in order to satisfy the commercial operation requirements of a coastal substation in Zhoushan, Zhejiang Province.

\section{Experimental}

\subsection{Materials}

In this study, the materials are melted in an electromagnetic furnace and poured into a $1250 \mathrm{~mm} \times 1000 \mathrm{~mm} \times 2250 \mathrm{~mm}$ cast iron mold. Table 1 summarizes the chemical compositions of alloys analyzed with an inductively coupled plasma optical emission spectrometer. A reference alloy, named $0 \mathrm{Er}$, has no Er addition, whereas $0.2 \mathrm{Er}$ and $0.56 \mathrm{Er}$ are modified with $\mathrm{Er}$ additions of $0.2 \%$ and $0.56 \%$, respectively. All testing alloys are hot-rolled (from 90 to $6 \mathrm{~mm}$ ) after a homogenization treatment. These alloys are recrystallized and thereafter subjected to cold rolling from 6 to $2 \mathrm{~mm}$ followed by a recrystallization treatment at 320 and $400{ }^{\circ} \mathrm{C}$ for $1 \mathrm{~h}$. This study focuses on $\mathrm{Al}-\mathrm{Mg}$ alloys used in the above-mentioned coastal substation. In this application, the status of alloys is fully annealed $\mathrm{O}$ temper. The solid solution strengthening of $\mathrm{Mg}$ atoms is
Table 1 Composition (wt \%) of Al-Mg-Er alloys tested in this study

\begin{tabular}{llllllllll}
\hline & $\mathrm{Mg}$ & $\mathrm{Mn}$ & $\mathrm{Cr}$ & $\mathrm{Fe}$ & $\mathrm{Cu}$ & $\mathrm{Zn}$ & $\mathrm{Si}$ & $\mathrm{Er}$ & $\mathrm{Al}$ \\
\hline $0 \mathrm{Er}$ & 2.4 & 0.1 & 0.2 & 0.3 & 0.1 & 0.1 & 0.25 & 0 & Bal \\
$0.2 \mathrm{Er}$ & 2.6 & 0.1 & 0.2 & 0.3 & 0.05 & 0.1 & 0.2 & 0.2 & Bal \\
$0.56 \mathrm{Er}$ & 2.6 & 0.1 & 0.2 & 0.3 & 0.07 & 0.1 & 0.23 & 0.56 & $\mathrm{Bal}$ \\
\hline
\end{tabular}
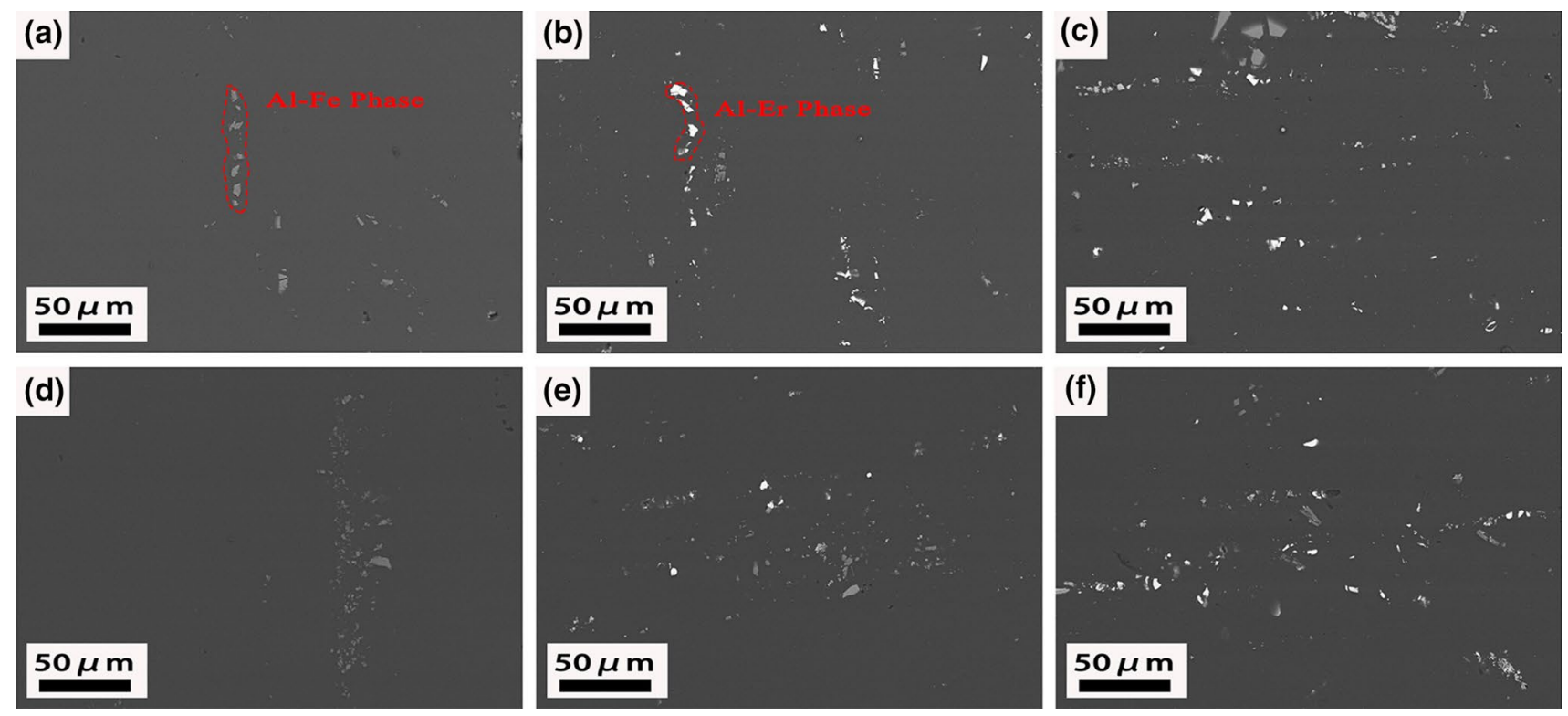

Fig. 1 Typical back-scattered electron images: a $0 \mathrm{Er}, \mathbf{b} 0.20 \mathrm{Er}, \mathbf{c} 0.56 \mathrm{Er}$ at $320{ }^{\circ} \mathrm{C} ; \mathbf{d} 0 \mathrm{Er}, \mathbf{e ~} 0.20 \mathrm{Er}, \mathbf{f} 0.56 \mathrm{Er}$ at $400{ }^{\circ} \mathrm{C}$ 

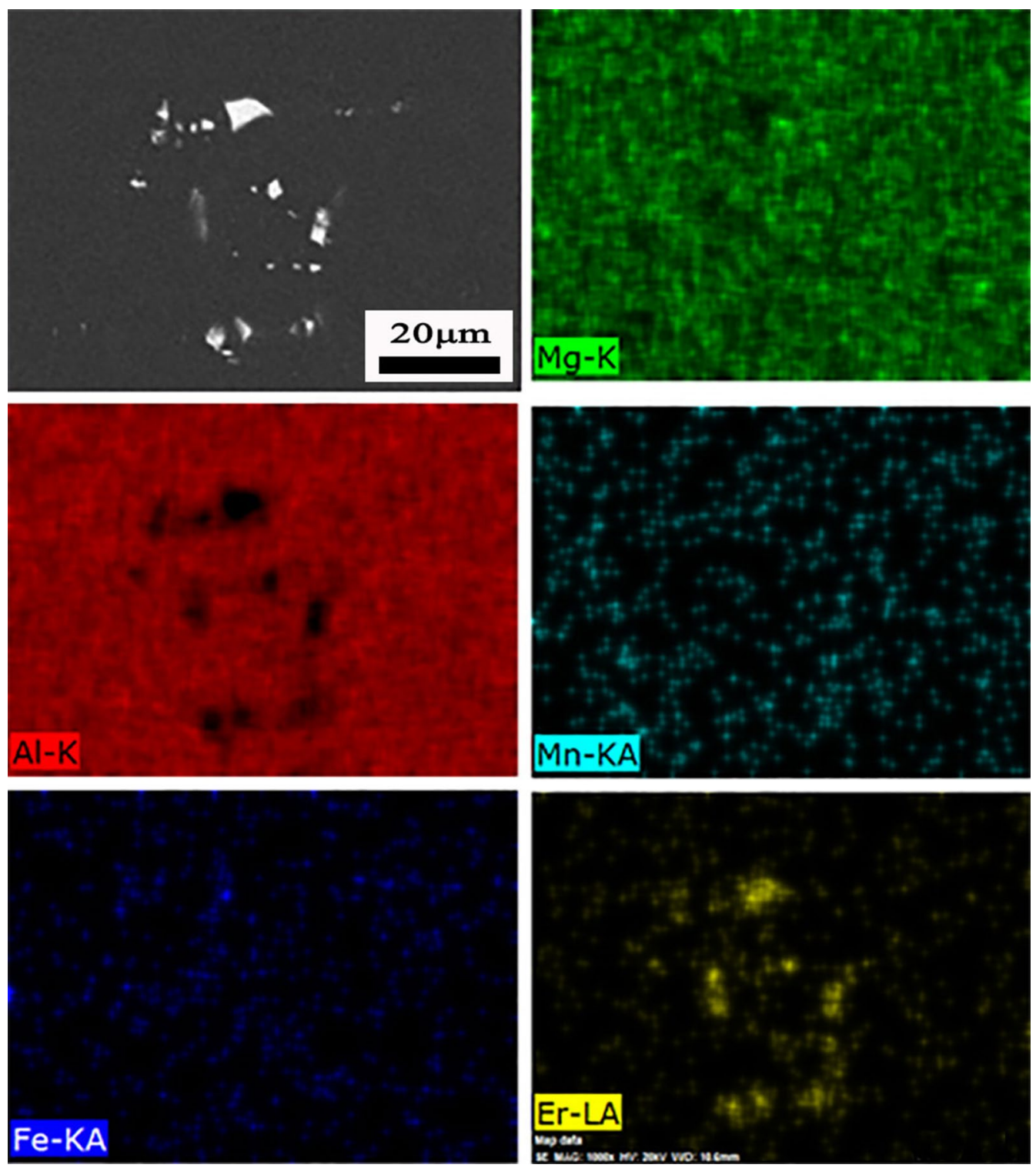

Fig. 2 EDS element mapping analysis of 0.56Er alloys showing Er enrichment of intermetallic particles

the main strengthening mechanism in the alloy. In this study, therefore, the corrosion and mechanical behavior of samples fully annealed at 320 and $400{ }^{\circ} \mathrm{C}$ are investigated.

\subsection{Tensile Testing}

Tensile specimens are machined from as-cast samples with a $2 \mathrm{~mm}$ thickness and $50 \mathrm{~mm}$ gauge length. Three flat specimens from each alloy are also employed to determine the tensile properties. The tensile test is performed at a strain rate of $0.5 \mathrm{~mm} / \mathrm{min}$ on a WDW-200D tester at room temperature.

\subsection{Corrosion Testing}

Prior to the conduct of each experiment, all alloys are cut to $40 \mathrm{~mm} \times 25 \mathrm{~mm} \times 2 \mathrm{~mm}$ dimensions. These specimens are polished with $1500 \#$ grade $\mathrm{SiC}$ papers and chemically cleaned by $10 \% \mathrm{NaOH}$ solution and $30 \% \mathrm{HNO}_{3}$ solution in sequence. Upon the completion of experiments, the specimens are washed with $30 \% \mathrm{HNO}_{3}$ to remove all corrosion products.

In order to assess the electrochemical corrosion properties, electrochemical potentiodynamic polarization tests are conducted using a three-electrode system on an 

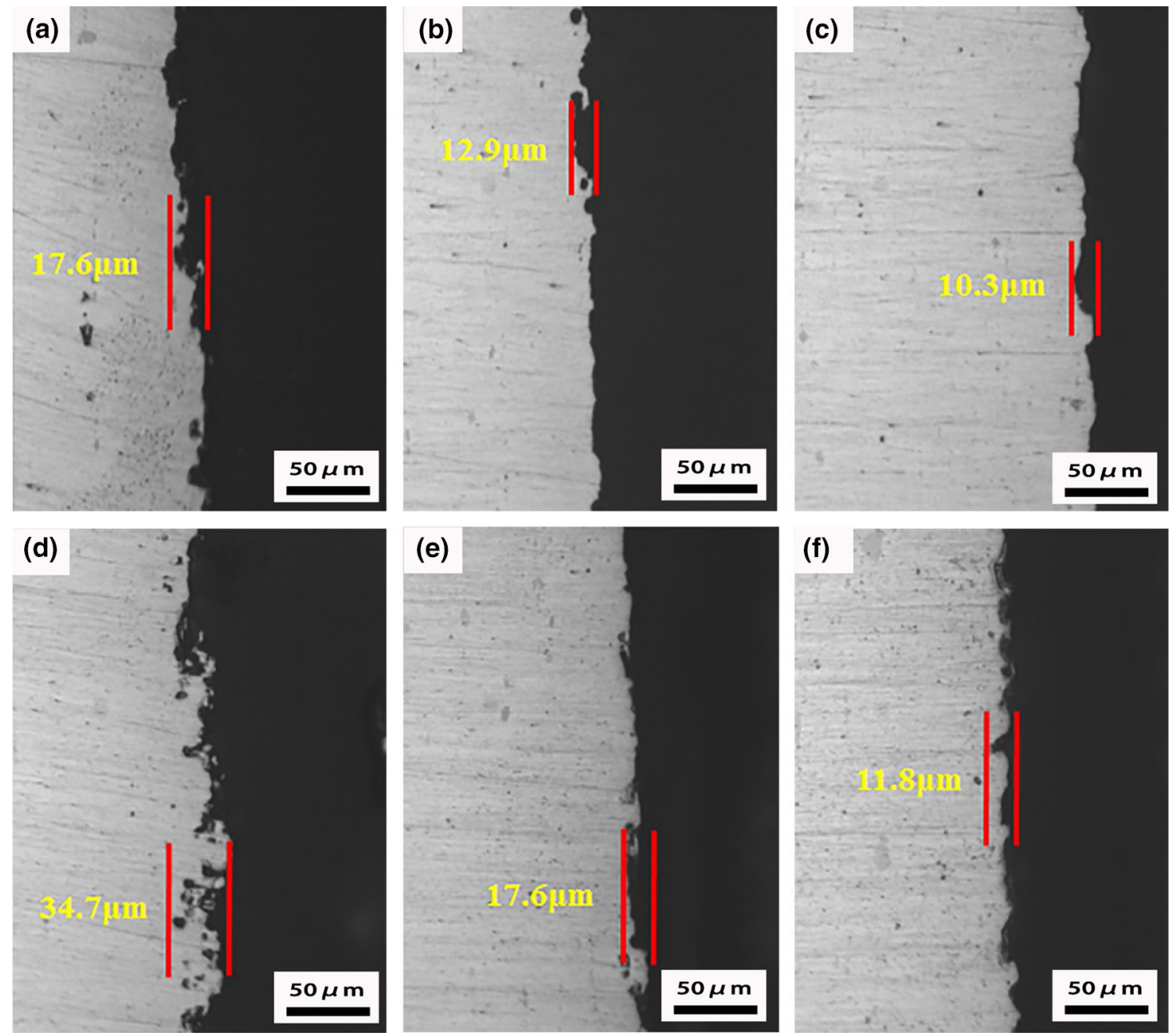

Fig. 3 Images of intergranular corrosion tests: a $0 \mathrm{Er}, \mathbf{b} 0.20 \mathrm{Er}, \mathbf{c} 0.56 \mathrm{Er}$ at $320{ }^{\circ} \mathrm{C} ; \mathbf{d ~} 0 \mathrm{Er}, \mathbf{e} 0.20 \mathrm{Er}, \mathbf{f} 0.56 \mathrm{Er}$ at $400{ }^{\circ} \mathrm{C}$

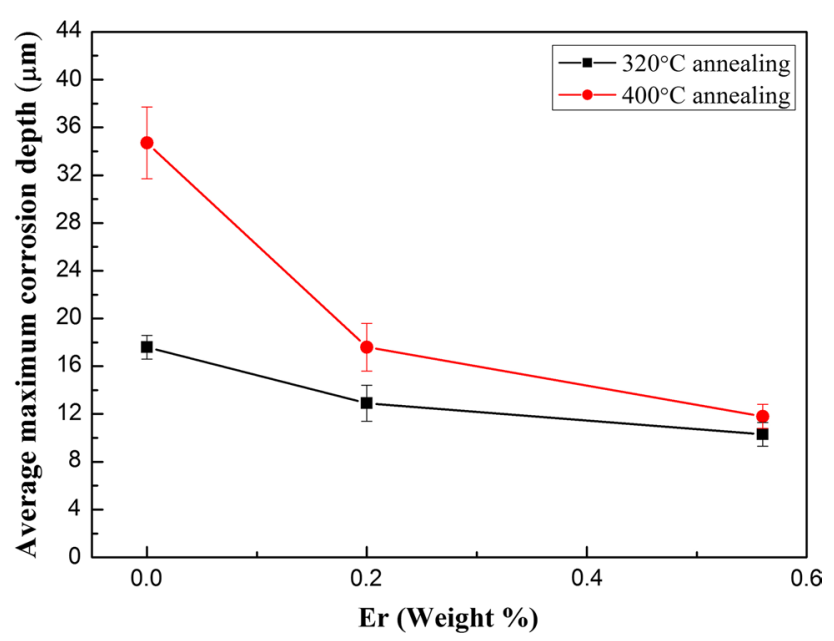

electrochemical workstation (VersaSTAT-3F). This workstation is saturated with a calomel electrode (SCE) as reference electrode, a platinum tablet as counter electrode, and a specimen as working electrode. All potentials in this work are referred to the SCE electrode. Potentiodynamic polarization experiments are performed from -0.6 to $0.8 \mathrm{~V}$ with a scan rate of $1 \mathrm{mV} / \mathrm{s}$ in a $3.5 \% \mathrm{NaCl}$ solution at room temperature.

All specimens are immersed in a corrosive solution $(30 \mathrm{~g}$ $\mathrm{NaCl}+1 \mathrm{~L} \mathrm{H}_{2} \mathrm{O}+10 \mathrm{~mL} \mathrm{HCl}$ ) at $35 \pm 2{ }^{\circ} \mathrm{C}$ for $24 \mathrm{~h}$ according to the intergranular corrosion testing requirement of GB/T7998-2005 (test method for intergranular corrosion of aluminum alloy) [22]. All alloys are salt spray-tested for $72 \mathrm{~h}$; however, the solution should be acidic $(\mathrm{pH}=3.0-3.3)$ to accelerate corrosion. The test is in accordance with GB/ T19746-2005 (Corrosion of metals and alloys-Alternate immersion test in salt solution) [23].

Fig. 4 Effect of Er content on average maximum corrosion depth in samples treated at 320 and $400{ }^{\circ} \mathrm{C}$ 

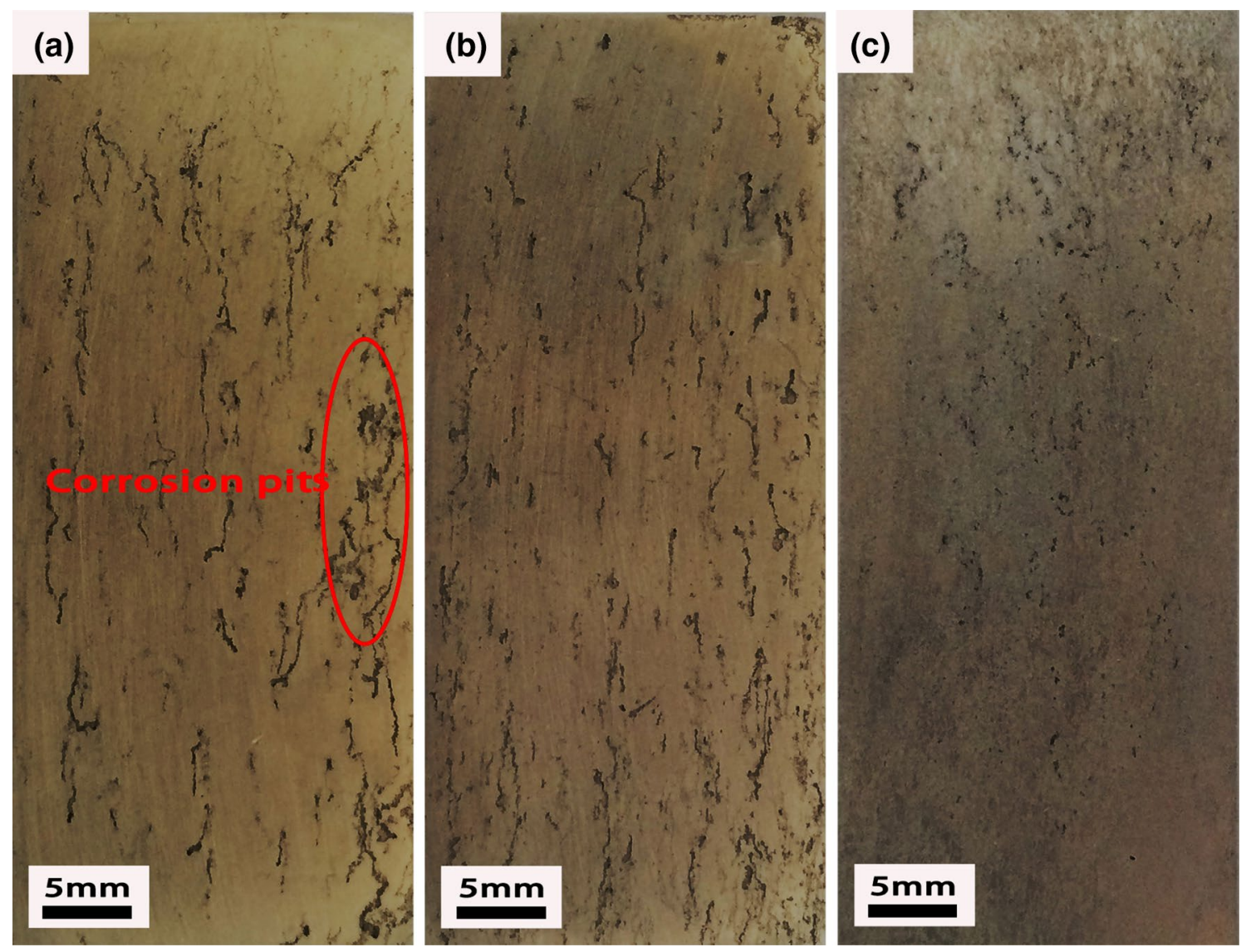

Fig. 5 Images of acid salt spray solution tests in samples treated at $400{ }^{\circ} \mathrm{C}: \mathbf{a} 0 \mathrm{Er}, \mathbf{b} 0.2 \mathrm{Er}, \mathbf{c} 0.56 \mathrm{Er}$

\subsection{Characterization}

The microstructural characterization of specimens is analyzed by optical microscopy (OM), scanning electron microscopy (SEM), and transmission electron microscopy (TEM). Specimens are polished with SiC paper of different grades and etched with Keller's reagent for OM and SEM characterizations. The slices for TEM observation are prepared by twin-jet polishing with an electrolyte solution consisting of $25 \% \mathrm{HNO}_{3}$ and $75 \%$ methanol at $-35^{\circ} \mathrm{C}$ with a constant current of $80 \mathrm{~mA}$. The TEM observations are performed in JEM2010 with a $200 \mathrm{kV}$ accelerating voltage. Fine-probe energy-dispersive X-ray spectroscopy (EDS) is employed to determine the composition.

\section{Results and Discussion}

Figure 1 shows the morphologies and distribution of intermetallic phases for the produced $\mathrm{Al}-2.6 \mathrm{Mg}-x \mathrm{Er}$ alloys. The similar shapes of intermetallic phases are revealed by the microstructures regardless of Er content and annealing temperature. By using SEM-EDS, Al-Er and Al-Fe phases are determined by SEM (white and gray contrasts, respectively). The Al-Fe phase is deleterious and brittle and mainly causes material failure induced by crack initiation. Element distributions are further investigated via EDS element mapping, which shows that Er is also incorporated in coarse constituent intermetallic particles (Fig. 2). The strength of alloys is attributed to Er-enriched intermetallic particles.

An immersion corrosion test is subsequently performed to evaluate the corrosion properties of samples. This method is originally used to measure the intergranular corrosion of high-magnesium aluminum alloy. The experimental results show that there is no distinct intergranular corrosion morphology in the cross section of the sample; however, there is a flocculent-dotted local corrosion pit. The local corrosion pits of $0 \mathrm{Er}, 0.2 \mathrm{Er}$, and $0.56 \mathrm{Er}$ aluminum alloys subjected to isothermal annealing at 320 and $400{ }^{\circ} \mathrm{C}$ are shown in Fig. 3 . Based on the cross section morphology of corrosion, the scope of local corrosion pits continues to become smaller with the addition of Er. The aforementioned scope is defined as the local pit depth to qualitatively evaluate the corrosion resistance of low-magnesium 5xxx aluminum alloy (in 


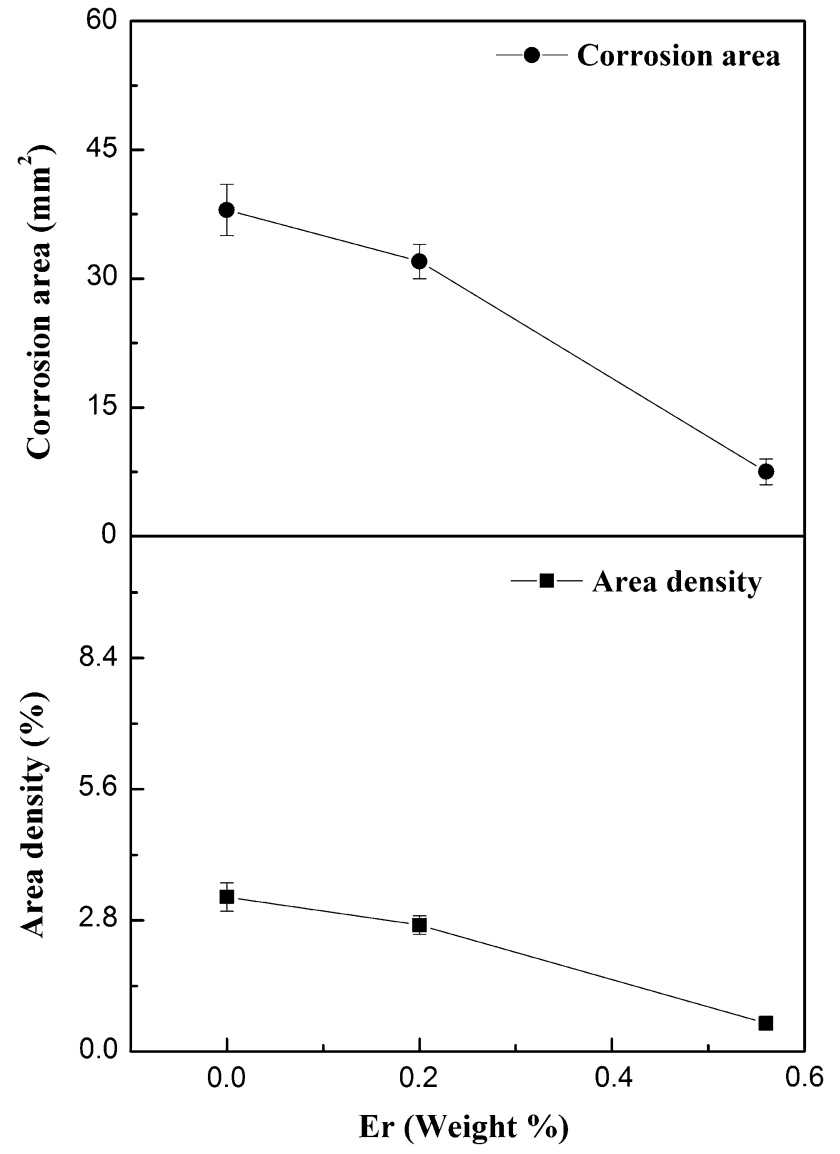

Fig. 6 Effect of Er content on corrosion area and area density in sample treated at $400{ }^{\circ} \mathrm{C}$

Fig. 3, the red line spacing is the local pit depth). In addition, the pitting corrosion is evaluated by the corrosion area and area density according to GBT18590-2001 [24]. The observation of maximum pit depth by optical microscopy is merely an assistant method to support the monitoring of pitting corrosion evolution observed by corrosion area and area density. The local pit depth of aluminum alloys without the rare earth element, Er, is larger, and the corrosion interface is uneven at $320{ }^{\circ} \mathrm{C}$. With the increase in Er content, the corrosion interface tends to be smooth, and the local pit depth decreases accordingly (Fig. 3a-c). When the annealing temperature is further raised to $400{ }^{\circ} \mathrm{C}$, it becomes evident that the corrosion resistance is worse than that at $320^{\circ} \mathrm{C}$, especially for the aluminum alloy without Er. Moreover, the measured local pit depth is approximately twice as deep as that which occurs at $320^{\circ} \mathrm{C}$ (Fig. $3 \mathrm{~d}-\mathrm{f}$ ). The corrosion resistance of aluminum alloy, however, is considerably improved by Er addition, and the local pit depth of $0.56 \mathrm{Er}$ is reduced to $1 / 3$ of that of $0 \mathrm{Er}$. According to the specific local pit depth measurement statistics (Fig. 4), the sensitivity of Er addition to corrosion in low-temperature annealing is less than that in high-temperature annealing. With the increase in Er content, the corrosion resistance of aluminum alloys is improved.

To further investigate the effect of Er on the corrosion resistance of $5 \times x x$ aluminum alloys, salt spray experiments are performed to analyze the relationship between $\mathrm{Er}$ content and corrosion resistance. After the salt spray test, long-strip local corrosion pits of varying degrees appear on the surface of samples. Figure 5 shows that the area of pitting decreases with the increase in Er content in the sample treated at $400{ }^{\circ} \mathrm{C}$. According to the difference in color contrast between the corrosion area and matrix, the area of corrosion pitting is determined by ImageJ, and the proportion of corrosion area is defined as "area density"; statistical results are shown in Fig. 6. The figure also shows that compared with $0 \mathrm{Er}$, the pitting area of $0.56 \mathrm{Er}$ decreases from 40 to $7 \mathrm{~mm}^{2}$. Meanwhile, the regularity of local corrosion is consistent with the pitting phenomenon that occurs in intergranular corrosion testing. With the increase in Er content, the corrosion resistance of aluminum alloy is accordingly improved.

Potentiodynamic polarization tests are conducted to determine the effect of Er addition on the electrochemical response of Al-2.6 Mg. Representative polarization curves for alloys with Er are presented in Fig. 7a. This demonstrates that Er addition leads to an evident increase in corrosion potential $\left(E_{\text {corr }}\right)$ [25]. The polarization curves of samples treated at different temperatures exhibit certain differences. Corrosion current densities $\left(i_{\text {corr }}\right)$ are obtained by Tafel extrapolation and presented in Fig. 7d, and the $i_{\text {corr }}$ values of all alloys are in the range $1.0-2.5 \mu \mathrm{A} / \mathrm{cm}^{2}$. With the increase in Er, $i_{\text {corr }}$ values decrease, indicating that Er addition can reduce the corrosion rate. It also means that the corrosion resistance of samples without Er addition is weak.

Electrochemical corrosion is employed to accelerate the corrosion process, and the surface morphology of samples is characterized by SEM. The corrosion solution used in electrochemical corrosion is similar to that utilized in immersion corrosion $\left(30 \mathrm{~g} \mathrm{NaCl}+1 \mathrm{~L} \mathrm{H}_{2} \mathrm{O}+10 \mathrm{~mL} \mathrm{HCl}\right)$. Figure 8 shows that the test method is consistent with the electrochemical potentiodynamic polarization test, indicating that the acceleration effect of corrosion is remarkable. Figure $8 \mathrm{a}-\mathrm{c}$ shows the corrosion surface of samples annealed at $320^{\circ} \mathrm{C}$ for $1 \mathrm{~h}$. Based on the degree of surface corrosion, which of $0 \mathrm{Er}$ is the most severe, its surface is highly fragmented, and all regions have eroded into a porous morphology (Fig. 8a). With Er addition, however, the proportion of corrosion area on the surface significantly decreases. The same phenomenon is observed in samples annealed at $400{ }^{\circ} \mathrm{C}$ (Fig. $8 \mathrm{~d}-\mathrm{f}$ ). After the annealing of $0.56 \mathrm{Er}$ sample at $400{ }^{\circ} \mathrm{C}$ for $1 \mathrm{~h}$, a significant improvement in corrosion 

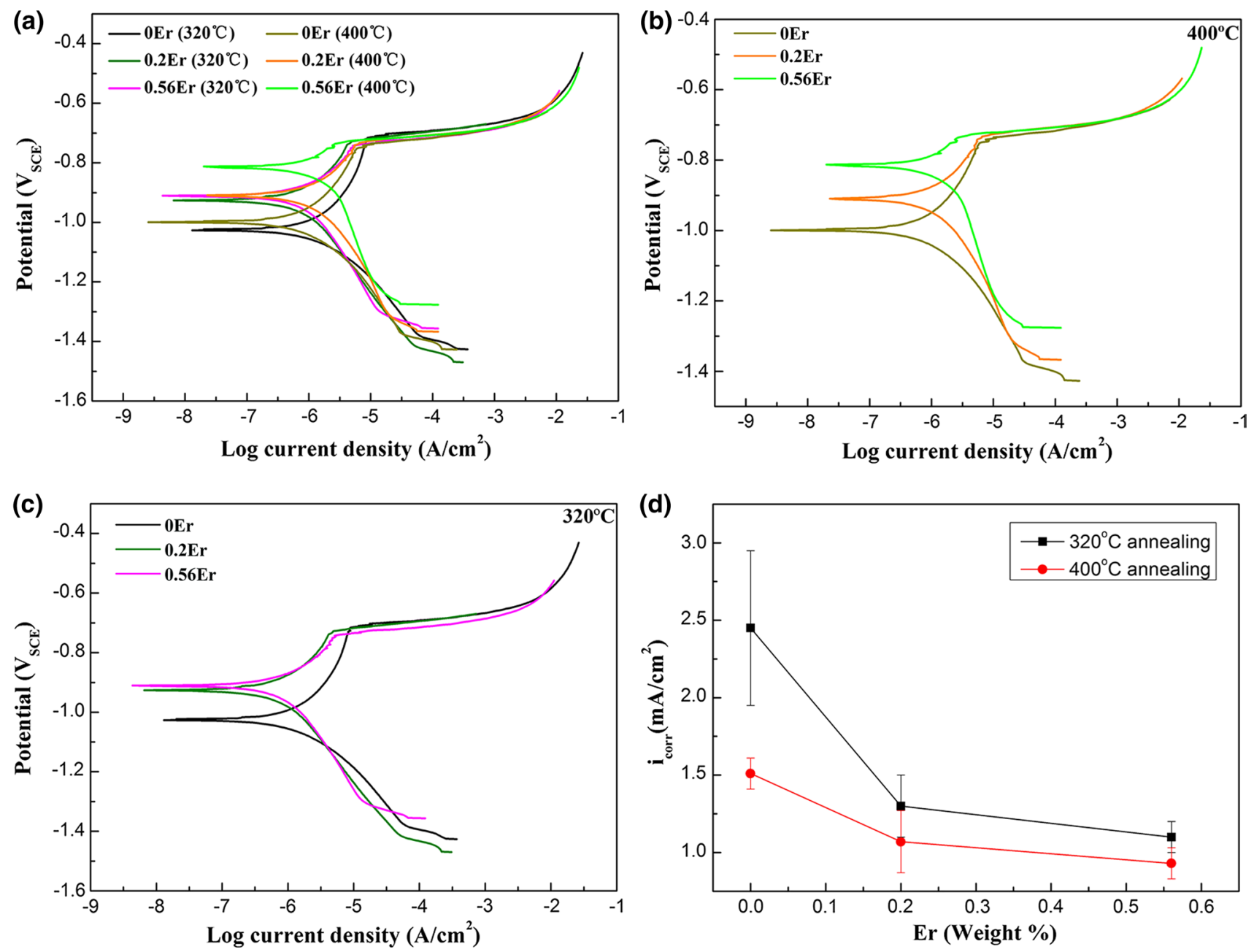

Fig. 7 a Potentiodynamic polarization curves of Al-2.6 Mg- $x$ Er alloys in samples treated at b $400{ }^{\circ} \mathrm{C}$, $\mathbf{c} 320{ }^{\circ} \mathrm{C}$; $\mathbf{d}$ effect of Er on corrosion of Al-2.6 Mg alloy measured in terms of corrosion current density from Tafel extrapolation

resistance is observed, as shown in Fig. 8f. The mass loss per unit area after 20-min electrochemical corrosion tests and subsequent cleaning of corrosion products for alloys with varying Er contents as presented in Fig. 9. With the increase in Er content, the mass loss of aluminum alloys is decreased after electrochemical corrosion tests. This is consistent with potentiodynamic polarization tests results and indicates that corrosion rate of $\mathrm{Al}-2.6 \mathrm{Mg}-x$ Er alloys decreasing with Er addition.

Based on the above experiments, it is concluded that the addition of Er improves the corrosion resistance of $5 \mathrm{xxx}$ low-Mg-Al alloys. It is widely known, however, that there is a certain constraint in the relationship between corrosion resistance and strength. It is also essential to ensure that the certain strength is achieved as Er improves the corrosion resistance of aluminum alloy. As shown in Fig. 10, tensile testing is performed, and it is found that with the increase in Er, the tensile strength of aluminum alloy treated at $400{ }^{\circ} \mathrm{C}$ is not reduced within the error range but slightly increases $(\sim 210 \mathrm{MPa})$. Nie et al. studied the effect of $\mathrm{Er}$ on the mechanical properties of Al-5 Mg alloys [26, 27] and found that increasing the Er content to a certain range considerably enhances the strength of high-magnesium aluminum alloy. An Er content that exceeds 0.4 wt\%, however, ceases to improve strength. In this study, it is deemed that an Er content that exceeds $0.2 \mathrm{wt} \%$ in low-magnesium aluminum alloy has no significant effect on strength improvement. As Er addition increases, however, the alloy's plastic properties are improved. This may be related to the decrease in the brittle $\mathrm{Al}-\mathrm{Fe}$ phase and its dispersion distribution, as shown in Fig. 1.

Figure 11 presents the relationship between corrosion (local corrosion area and local corrosion depth) and 

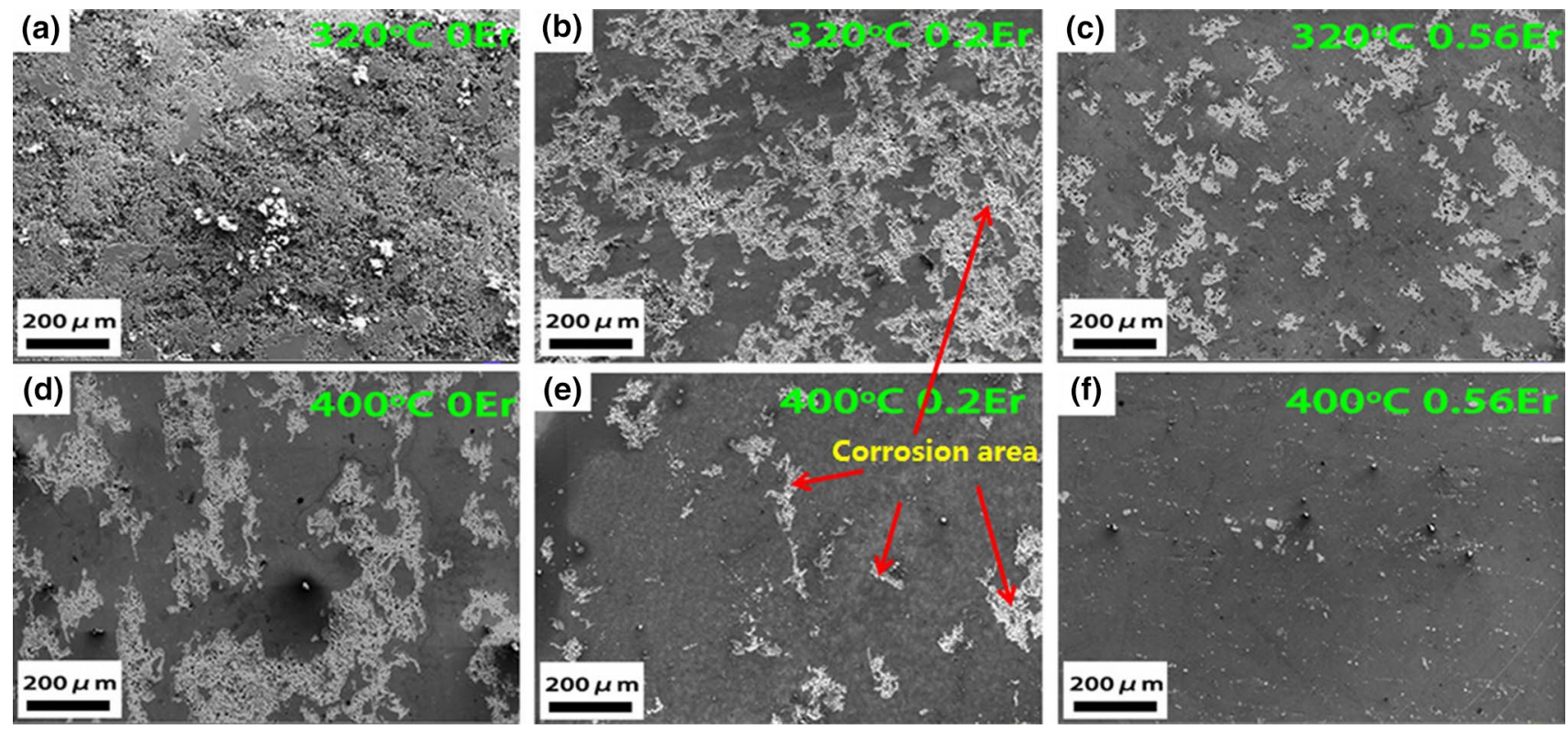

Fig. 8 Images of electrochemical corrosion tests: a $0 \mathrm{Er}, \mathbf{b} 0.20 \mathrm{Er}$, c $0.56 \mathrm{Er}$ at $320{ }^{\circ} \mathrm{C}$; d $0 \mathrm{Er}$, e $0.20 \mathrm{Er}, \mathbf{f} 0.56 \mathrm{Er}$ at $400{ }^{\circ} \mathrm{C}$

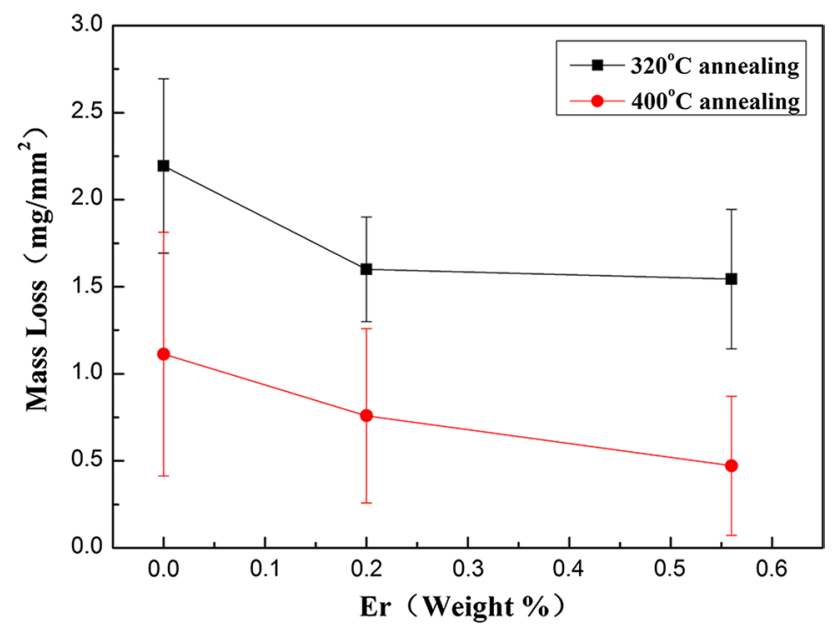

Fig. 9 Mass loss per unit area following electrochemical corrosion tests 20 min and subsequent cleaning of corrosion products

tensile strength in terms of Er content. The addition of $\mathrm{Er}$ to $\mathrm{Al}-2.6 \mathrm{Mg}$ alloy leads to a significant improvement in corrosion resistance. It is should be noted that this improvement does not result in a decrease in strength. The improvement in properties could be attributed to the formation of $\mathrm{Al}_{3} \mathrm{Er}$ on grain boundaries that potentially disrupts the $\mathrm{Mg}_{2} \mathrm{Al}_{3}$ network or even alters the $\mathrm{Mg}_{2} \mathrm{Al}_{3}$ formation kinetics $[5,7]$. In order to compensate for the strength reduction caused by the decrease in $\mathrm{Mg}$ content, the recrystallization temperature of the alloy is increased by adding Er; the

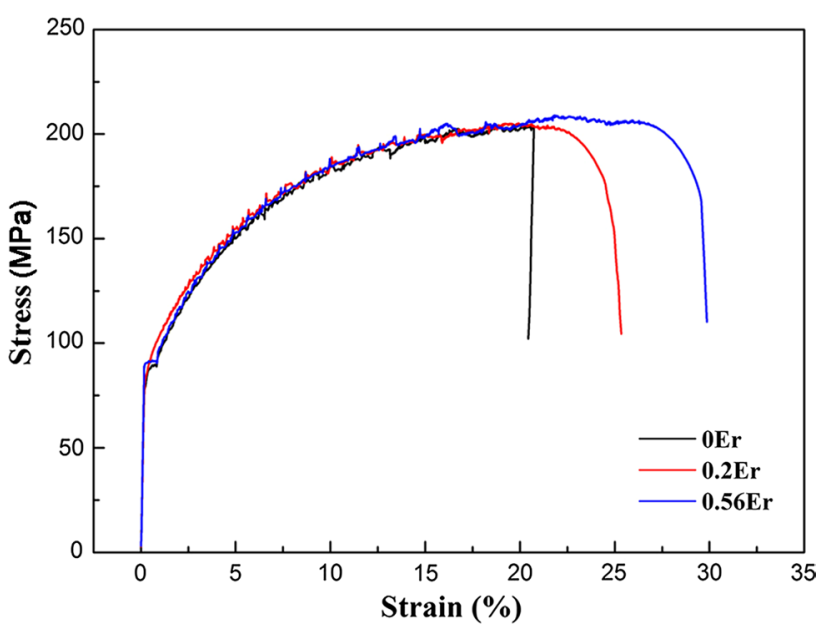

Fig. 10 Effect of Er content on tensile strength of aluminum alloy treated at $400{ }^{\circ} \mathrm{C}$

precipitate-strengthening mechanism leads to an increase in alloy strength.

It is widely known that performance is determined by the microstructure. To clarify the high-strength mechanism and corrosion resistance of aluminum alloy with Er addition, TEM is employed. This makes it possible to observe the annealing microstructures, dislocations, and precipitates at the grain boundaries of cold-rolled aluminum alloys at 320 and $400{ }^{\circ} \mathrm{C}$, as shown in in Figs. 12 and 13, respectively. 


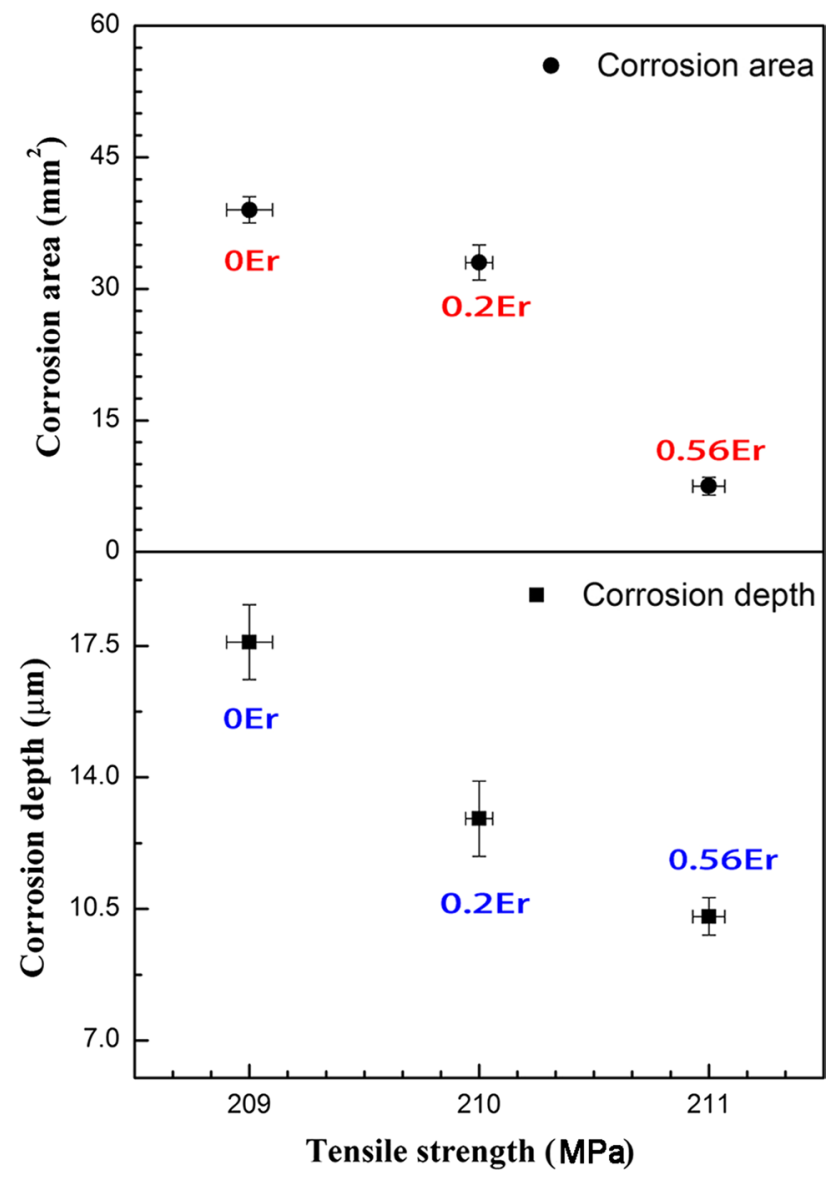

Fig. 11 Simultaneous effects of Er on corrosion and tensile strength of $\mathrm{Al}-2.6 \mathrm{Mg}$ alloy

A large number of substructures are formed at $320^{\circ} \mathrm{C}$ in the cold-rolled aluminum alloy. In 0Er samples (Fig. 12a), numerous sub-grains are formed (red arrows pointing out from the inside). During the recovery of alloys that are cold-rolled at $320{ }^{\circ} \mathrm{C}$, the dislocations in cell boundaries are rearranged and eradicated, and the cell is transformed into sub-grains. The dislocations (marked with red dotted lines) are regularly arranged on the sub-grain boundaries and are barely visible inside the sub-grains. The degree of recovery in $0.56 \mathrm{Er}$, however, is lower than that in $0 \mathrm{Er}$, and the extent of dislocation defect is also greater (Fig. 12b). Dislocations that occur in striped form accumulate in the cell, and only a few sub-grains appear, indicating that the recovery in $0.56 \mathrm{Er}$ samples is inhibited. Based on previous studies, $\mathrm{Al}_{3} \mathrm{Er}$ precipitate formed by Er addition pins the dislocation and hinders the migration of grain boundaries, thus inhibiting the recrystallization process and increasing the recrystallization temperature. In contrast, the aluminum alloy cold-rolled at $400{ }^{\circ} \mathrm{C}$ is completely recrystallized, and numerous dislocation defects disappear (Fig. 13). In
0Er samples (Fig. 13a), more dispersed precipitates form at the grain boundary. In $0.56 \mathrm{Er}$ samples, however, there is no precipitate at the grain boundary (Fig. 13b, c), thereby improving the corrosion resistance with Er addition. More dislocation defects are also found in the grain interior, as shown in Fig. 13b, c.

The resistance corrosion of alloys is related to the oxidation film and precipitates located on the grain boundaries. The experimental results (Figs. 3, 5) indicate that the corrosion resistance of alloys gradually improves with the increase in Er content. According to the typical characteristic of alloys, aluminum alloys form an oxidation film whose structure is $\gamma-\mathrm{Al}_{2} \mathrm{O}_{3}$ in the air. The film has a spinel structure with some defects. The grain structure of $\gamma-\mathrm{Al}_{2} \mathrm{O}_{3}$ indicates that the $\mathrm{O}$ atoms are distributed in the cell, and $\mathrm{Al}$ atoms randomly fill the defects in the cell; however, there are 32 defects in the cell. Based on a previous research [28], $\mathrm{Al}$ atoms only fill 64/3 defects; hence, $8 / 3$ defects are blank in the cell. When Er is added to aluminum alloys, Er atoms enter into the blank defects because they have a stronger affinity with oxygen. The oxidation film becomes more dense and stable, thus enhancing the alloy's corrosion resistance.

Meanwhile, the aluminum alloy easily corrodes in an electrolyte that contains $\mathrm{Cl}^{-}$, where the active $\mathrm{Cl}^{-}$first is adsorbed on the alloy surface and thereafter destroys the oxide film. The potential of damaged area changes, and the anode area easily is corrode. The occurrence of electrode reaction increases the aggregation rate of $\mathrm{Cl}^{-}$and eventually causes a large quantity of chlorides to enter into the pore, thereby aggravating corrosion and ultimately producing pitting corrosion. The oxidation film becomes denser because of Er addition, and the pitting resistance sensitivity is enhanced.

Investigations on the relationship between grain boundary orientation and corrosion performance are reported. These investigations $[29,30]$ indicate that an alloy with a small boundary orientation has a better corrosion resistance. This is because such an orientation could lower the probability of precipitation in the grain boundary, thus improving the alloy's corrosion resistance. It is generally assumed that the sub-grain structure has a smaller grain boundary orientation. The addition of Er increases the recrystallization temperature, and the alloy is formed in the sub-grain when annealed at $320^{\circ} \mathrm{C}$. The corrosion resistance of alloys annealed at $320^{\circ} \mathrm{C}$ is therefore more superior compared with alloys annealed at $400{ }^{\circ} \mathrm{C}$. The addition of Er, particularly with increasing Er content, slows down the recrystallization process. The dispersed $\mathrm{Al}_{3} \mathrm{Er}$ precipitates perform a function in pinning 
(a)
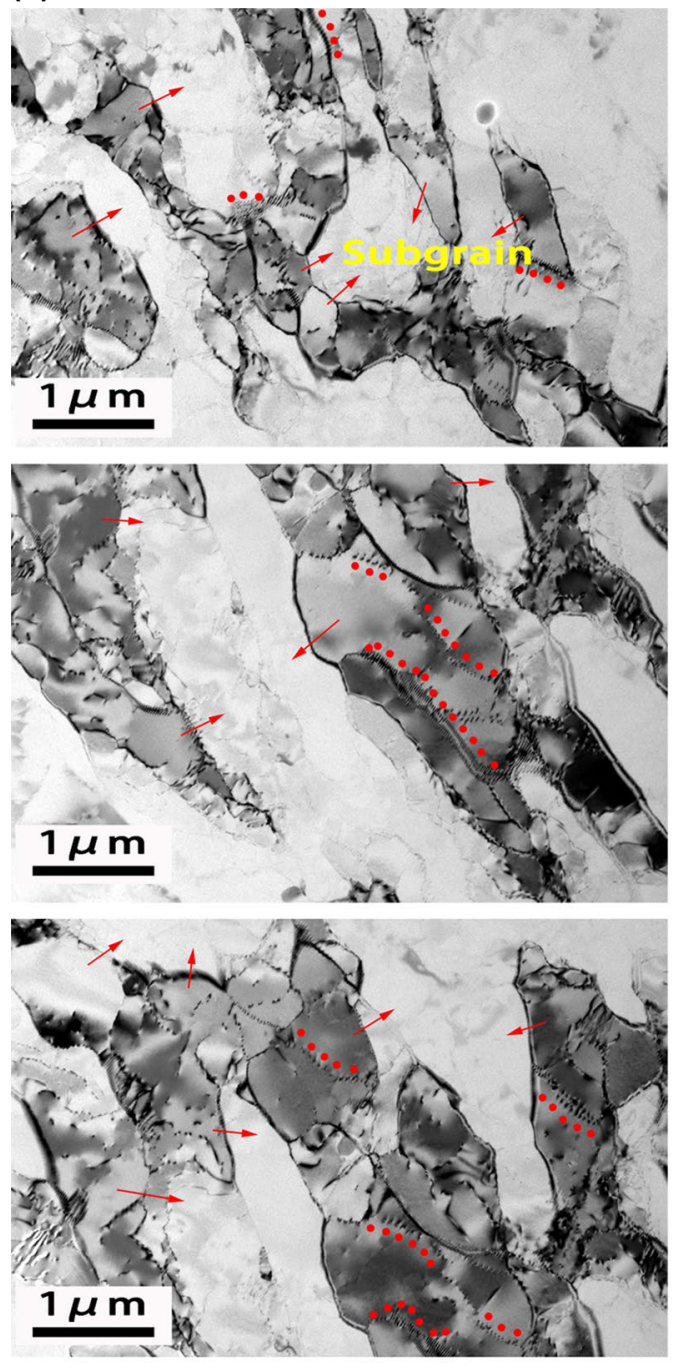

OEr $/ 320^{\circ} \mathrm{C}$ (b)
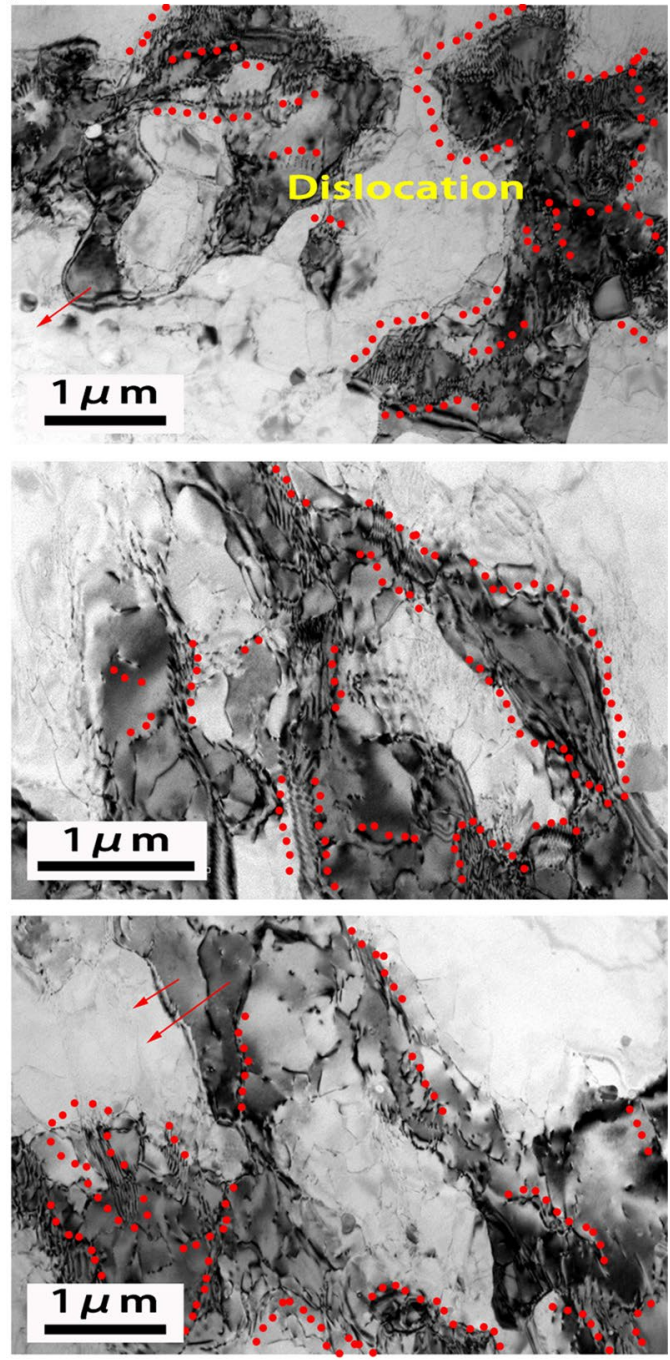

$0.56 \mathrm{Er} / 320^{\circ} \mathrm{C}$

Fig. 12 Bright-filled TEM image of alloys annealed at $320^{\circ} \mathrm{C}$ : a $0 \mathrm{Er}, \mathbf{b} 0.56 \mathrm{Er}$

dislocations at 320 and $400{ }^{\circ} \mathrm{C}$, thus ensuring high material strength [30].

In previous studies [31, 32], intergranular corrosion is the main corrosion mode in high-magnesium aluminum alloys. This is mainly because of the continuous precipitation of $\beta-\mathrm{Al}_{3} \mathrm{Mg}_{2}$ at the grain boundaries of $\mathrm{Al}-\mathrm{Mg}$ alloys with an $\mathrm{Mg}$ content that exceeds 3.5\%. The addition of Er significantly increases the recrystallization temperature; thus, a reverse stabilization treatment can be used to improve the intergranular corrosion resistance in high-magnesium aluminum alloys by Er addition. Among the low-magnesium aluminum alloys in current use, however, pitting is dominant instead of intergranular corrosion. It is demonstrated that Er addition improves not only the intergranular corrosion resistance in high-magnesium aluminum alloys, but also the pitting corrosion resistance in low-magnesium aluminum alloys because the oxidation film becomes more dense and stable.

Over the past 2 years, the newly designed $\mathrm{Al}-\mathrm{Mg}-\mathrm{Er}$ alloy has been tested in the coastal substation in Zhoushan, Zhejiang Province. As shown in Fig. 14, both iron and copper in the pilot site erode to varying degrees over time. The designed alloy, however, has retained its original morphology (with practically no trace of erosion) in the coastal environment during these years. 


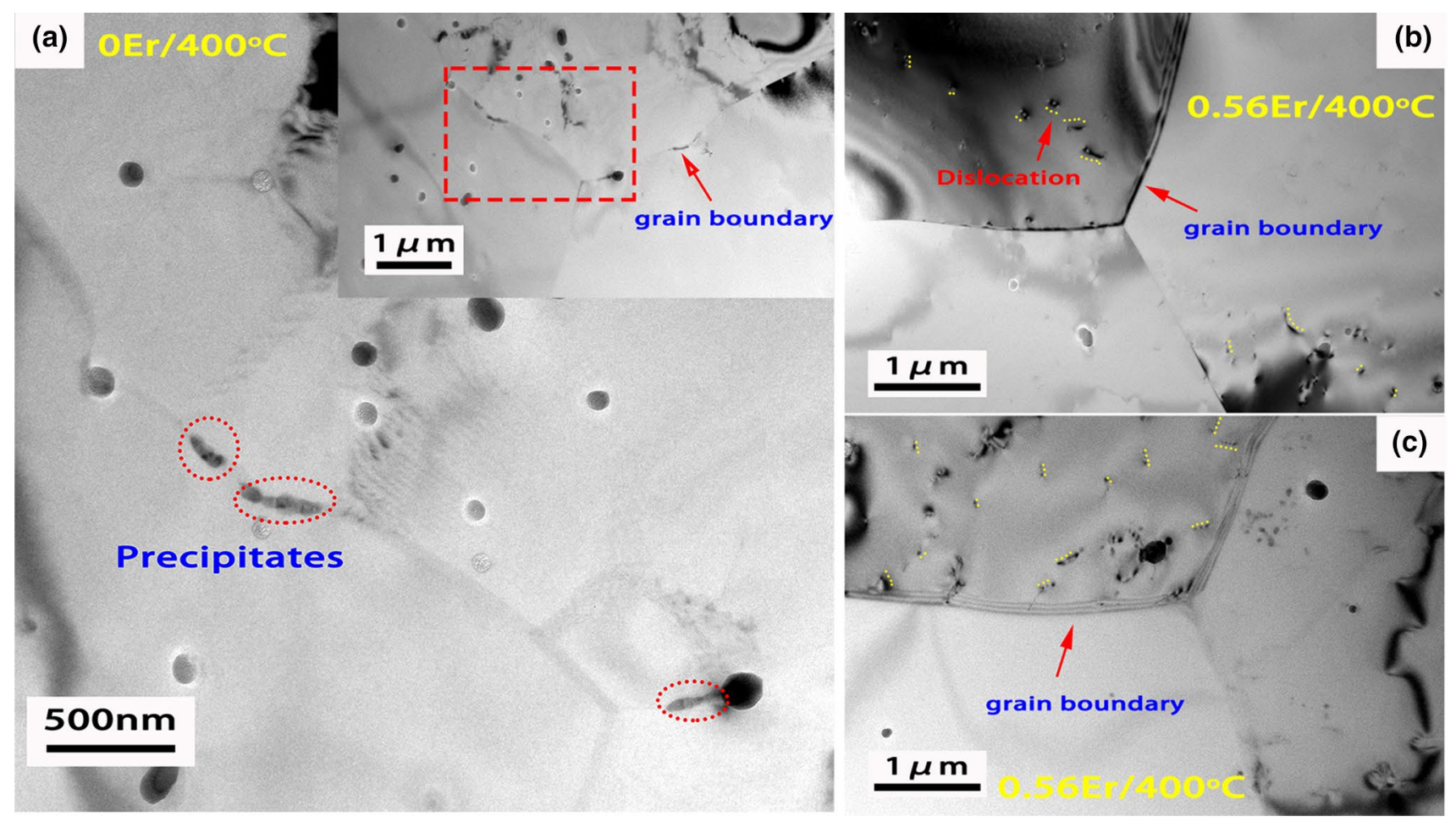

Fig. 13 Bright-filled TEM images of alloys annealed at $400{ }^{\circ} \mathrm{C}: \mathbf{a} 0 \mathrm{Er}, \mathbf{b}, \mathbf{c} 0.56 \mathrm{Er}$

(a)

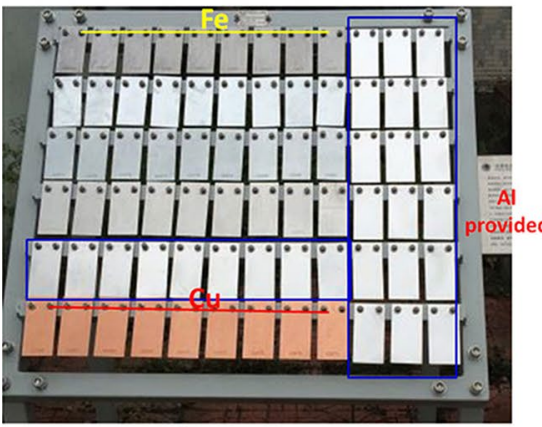

Before Test (b)

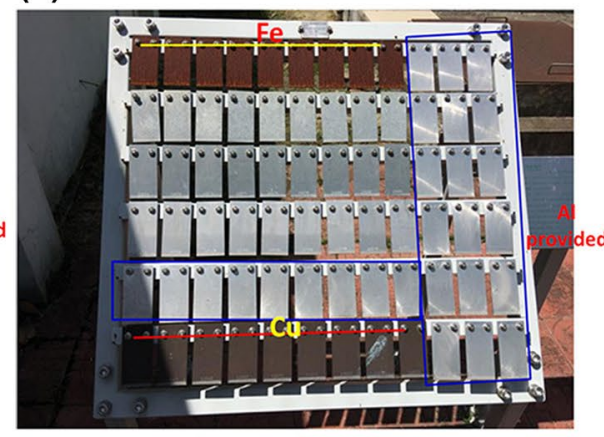

After Test (1 year) (c)

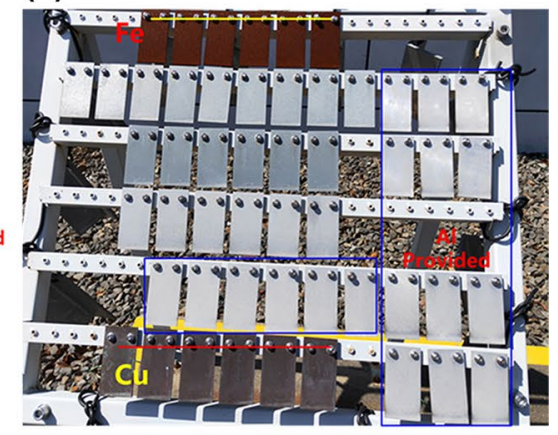

After Test (2 years)

Fig. 14 Samples in coastal substations $\mathbf{a}$ before test ( 0 year), $\mathbf{b}$ after 1 year, $\mathbf{c}$ after 2 years

\section{Conclusion}

In this work, the effects of Er on the microstructure, mechanical properties, and corrosion behavior of 5052 aluminum alloys are investigated. The results show that the corrosion resistance of these alloys can be improved on the premise of ensuring high strength by adding $\mathrm{Er}$ to $5 \mathrm{xxx}$ low-magnesium aluminum alloy. Moreover, the field monitoring experiments over the last 2 years have confirmed that the newly designed alloy exhibits better corrosion resistance than other alloys.
Acknowledgements The work was financially supported by the National Natural Science Foundation of China (Nos. U1860206, 51601011, 51874023), the Fundamental Research Funds for the Central Universities (No. FRF-TP-18-003B1), the Recruitment Program of Global Experts, the State Grid Scientific and Technological Research Program of China (No. 5211DS17001X).

\section{References}

[1] W. Huo, J. Hu, H. Cao, Y. Du, W. Zhang, Y. Zhang, J. Alloys Compd. 781, 680 (2019) 
[2] R.H. Jones, D.R. Baer, M.J. Danielson, J.S. Vetrano, Metall. Mater. Trans. A 32, 1699 (2001)

[3] J.A. Lyndon, R.K. Gupta, M.A. Gibson, N. Birbilis, Corros. Sci. 70, 290 (2013)

[4] S. Seetharaman, C. Blawert, B.M. Ng, J. Alloys Compd. 648, 759 (2015)

[5] Z.R. Nie, H. Huang, K.Y. Gao, B.L. Li, W. Wang, Z.Y. Chen, L. Rong, S.P. Wen, H.M. Li, T.Y. Zuo, Mater. Sci. Forum 706, 329 (2012)

[6] F. Rosalbino, E. Angelini, S. De Negri, A. Saccone, S. Delfino, Intermetallics 11, 435 (2003)

[7] Z. Nie, J. Fu, G. Xu, T.Z.J. Yang, Mater. Sci. Forum 396, 1731 (2002)

[8] C.H. Cui, K.Y. Gao, Z.R. Nie, S.P. Wen, H. Huang, Corros. Prot. 32, 94 (2011)

[9] Y. Wang, Q.L. Pan, Y.F. Song, C. Li, Z.F. Li, Q. Chen, Z.M. Yin, Trans. Nonferrous Metals Soc. China 23, 3235 (2013)

[10] Y. Riddle, T. Sanders, Metall. Mater. Trans. A 35, 341 (2004)

[11] Y. Ding, K. Gao, S. Guo, S. Wen, H. Huang, X. Wu, Z. Nie, D. Zhou, Mater. Charact. 147, 262 (2019)

[12] Y.F. Shen, R.G. Guan, Z.Y. Zhao, R.D.K. Misra, Acta Mater. 100, $247(2015)$

[13] Y. Zhang, Z. Yin, J. Zhang, Q. Pan, Z. Peng, Rare Metal Mater. Eng. 31, 167 (2002)

[14] Y. Wang, R.K. Gupta, N.L. Sukiman, R. Zhang, C.H.J. Davies, N. Birbilis, Corros. Sci. 73, 181 (2013)

[15] V. Ocenasek, M. Slamova, Mater. Charact. 47, 157 (2001)

[16] J.D. Lin, D.N. Seidman, D.C. Dunand, Mater. Sci. Eng. A 754, 447 (2019)
[17] C.B. Fuller, A.R. Krause, D.C. Dunand, D.N. Seidman, Mater. Sci. Eng. A 338, 8 (2002)

[18] YuA Filatov, V.I. Yelagin, V.V. Zakahrov, Mater. Sci. Eng. A 280, 97 (2000)

[19] H. Li, H. Wang, X. Liang, Y. Wang, H. Liu, J. Mater. Eng. Perform. 21, 83 (2012)

[20] S.P. Wen, Z.B. Xing, H. Huang, B.L. Li, W. Wang, Z.R. Nie, Mater. Sci. Eng. A 516, 42 (2009)

[21] S.P. Lin, Z.R. Nie, H. Huang, B.L. Li, Mater. Des. 31, 1607 (2010)

[22] GB/T 7998-2005, National Standard of China, Test Method for Inter-granular Corrosion of Aluminum Alloys

[23] GB/T 19764-2005, National Standard of China, Corrosion of Metals and Alloys-Alternate Immersion Test in Salt Solution

[24] GB/T 18590-2001, National Standard of China, Corrosion of Metals and Alloys-Evaluation of Pitting Corrosion

[25] J.Y. Gao, X.B. Liu, H.F. Zhou, X.F. Zhang, Acta Metall. Sin. (Engl. Lett.) 31, 1233 (2018)

[26] W.J. Lv, B.L. Li, P. Qi, Z.R. Nie, Mater. Sci. Forum 898, 35 (2017)

[27] X.L. Wu, Z.R. Nie, S.P. Wen, K.Y. Gao, H. Huang, Mater. Sci. Forum 877, 211 (2017)

[28] A.J. Davenport, Y. Yuan, R. Ambat, Mater. Sci. Forum 641, 519 (2006)

[29] L. Tan, T.R. Allen, Corros. Sci. 52, 548 (2010)

[30] K.L. Kendig, D.B. Miracle, Acta Mater. 50, 4165 (2002)

[31] S.X. Lin, X.R. Chu, Z.M. Yue, Acta Metall. Sin. (Engl. Lett.) 31, $1281(2018)$

[32] N. Thangapandian, S.B. Prabu, K.A. Padmanabhan, Acta Metall. Sin. (Engl. Lett.) 32, 835 (2019) 